\title{
Determinan Perilaku Remaja Putri Melakukan SADARI dalam Upaya Deteksi Dini Kanker Payudara
}

\author{
Siti Masita \\ Program Studi Ilmu Keperawatan STIKes Hang Tuah Pekanbaru, Jl Mustafa Sari No 5 Tangkerang \\ Selatan Pekanbaru, Telp. (0761)33815 \\ Email:sitimasita2404@gmail.com
}

\begin{abstract}
Abstrak
Perilaku SADARI (pemeriksaan payudara sendiri) sangat penting bagi remaja putri. Pemeriksaan payudara sendiri adalah salah satu cara mendeteksi adanya benjolan atau tumor pada payudara. Jenis penelitian yang digunakan kuantitatif analitik dengan desain cross sectional. Sampel pada penelitian ini berjumlah 107 remaja putri menggunakan teknik random sampling dengan cara diacak. Pada penelitian ini orang terdekat dan sumber informasi sangat mempengaruhi remaja putri melakukan pemeriksaan payudara sendiri. Diharapkan kepada pihak SMA Negeri 5 Pekanbaru untuk melakukan promosi kesehatan terkait pencegahan kanker payudara dengan cara melakukan pemeriksaan payudara sendiri (SADARI).

Kata kunci: Perilaku Remaja Putri, Pemeriksaan Payudara Sendiri (SADARI), Kanker Payudara.
\end{abstract}

\section{Abstract}

BSE behavior (breast self-examination) is very important for young women. Breast self-examination is one way to detect lumps or tumors in the breast. This type of research is quantitative analytic with cross sectional design. The sample in this study amounted to 107 teenage girls using random sampling techniques by randomizing. In this study the closest person and source of information greatly affect the young women doing breast self-examination. It is expected that the Pekanbaru 5 High School will conduct health promotion related to breast cancer prevention by conducting breast self-examination (BSE).

Keywords : Behavior of Adolescent girls, Self Breast Examination (BSE), Breast Cancer.

\section{Pendahuluan}

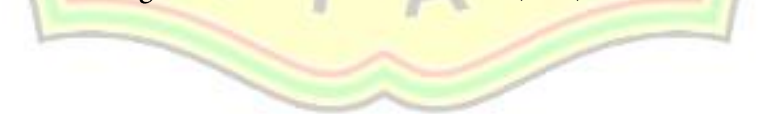

Kejadian kematian dan pravelensi kanker payudara di dunia tahun 2012, 43,3 \% dan kematian akibat kanker payudara 12,9\% dengan kata lain kanker payudara sebesar 40 per 100.000 perempuan. Tahun 2011 estimasi jumlah kasus baru dengan penyakit kanker payudara sebanyak 711 kasus, dan meningkat menjadi 769 kasus pada tahun 2013. Data Dinas Kesehatan provinsi Riau Pekanbaru, (2016) Kanker payudara adalah penyebab kematian terbesar setiap tahunnya. Lebih dari 30\% kematian akibat kanker payudara. Di Provinsi Riau, cakupan deteksi dini kanker payudara sebesar $1,16 \%$. Benjolan pada payudara pun bisa dijumpai pada wanita yang memasuki usia 20 tahun. Survei terakhir dunia menjelaskan setiap tiga menit ditemukan penderita kanker payudara dan setiap 11 menit ditemukan wanita meninggal akibat kanker payudara (Setiati, 2009).

Usia remaja adalah kelompok yang telah memasuki usia subur. Payudara umumnya mulai tumbuh ketika anak usia 9-11 tahun atau ketika anak mulai menstruasi. Dengan perkembangan zaman sekarang penyakit kanker payudara mulai mengarah ke usia yang lebih muda pada usia 13-20 tahun, oleh karena itu sangat perlu untuk mendeteksi dini sebagai 
upaya pencegahan kanker payudara. Mendeteksi dini kanker payudara dilakukan pada hari ke 7-10 setelah haid terakhir. (Lubis, 2017).

Perilaku SADARI (pemeriksaan payudara sendiri) sangat penting bagi Remaja putri untuk mengetahui benjolan di payudaranya. Karena hampir $85 \%$ benjolan ditemukan oleh penderitanya sendiri. Melakukan SADARI tidak membutuhkan biaya, tidak berbahaya, dan juga nyaman. (Wardhani, 2017). Berdasarkan latar belakang tersebut, peneliti tertarik untuk mengetahui hubungan pengetahuan, sikap, orang terdekat, dan sumber informasi pada remaja dengan melakukan pemeriksaan payudara sendri (SADARI).

\section{Metode Penelitian}

Penelitian ini merupakan penelitian yang digunakan kuantitatif analitik dengan desain cross sectional. Dengan 107 responden remaja putri menggunakan teknik random sampling dengan cara diacak. Alat pengumpulan data menggunakan kuesioner. Analisa yang digunakan adalah analisa univariat dan analisa bivariat dengan uji chi-square.

\section{Hasil dan Pembahasan}

Tabel 1. Karakteristik Responden Umur

\begin{tabular}{llll}
\hline No & Umur & Jumlah & Presentase \\
\hline 1. & $15 \mathrm{Th}$ & 14 & 13,1 \\
\hline 2. & $16 \mathrm{Th}$ & 42 & 39,3 \\
\hline 3. & $17 \mathrm{Th}$ & 51 & 47,7 \\
\hline \multicolumn{2}{l}{ Total } & 107 & 100,0
\end{tabular}

Berdasarkan tabel 1 diatas bahwa mayoritas remaja putri berusia 17 tahun sebanyak 51 orang $(47,7 \%)$, berusia 16 tahun sebanyak 42 orang (39,3\%), dan yang berusia 15 tahun sebanyak 14 orang $(13,1 \%)$.

Tabel 2. Ditrubusi Responden Berdasarkan Tingkat Pengetahuan Terhadap SADARI

\begin{tabular}{llll}
\hline No & Pernyataan & $\begin{array}{l}\text { Tidak } \\
\text { Melakukan }\end{array}$ & Melakukan \\
\hline 1. & Kurang & $24(72,7 \%)$ & $9(27,3 \%)$ \\
\hline 2. & Baik & $45(60,8 \%)$ & $29(39,2 \%)$ \\
\hline & Total & 69 & 38 \\
\hline
\end{tabular}

Hasil uji Chi -Square diperoleh $p$ value $0,234>\propto(0,05)$ yang berarti tidak terdapat hubungan antara pengetahuan dengan pemeriksaan payudara sendiri di SMA Negeri 5 Pekanbaru.

Tabel 3. Ditrubusi Responden Berdasarkan Sikap Terhadap SADARI

\begin{tabular}{llll}
\hline No & Pernyataan & $\begin{array}{l}\text { Tidak } \\
\text { Melakukan }\end{array}$ & Melakukan \\
\hline 1. & Negatif & $21(77,8 \%)$ & $6(22,2 \%)$ \\
\hline 2. & Positif & $48(60,0 \%)$ & $32(40,0 \%)$ \\
\hline & Total & 69 & 38
\end{tabular}

Hasil uji Chi -Square diperoleh $p$ value $0,095>\propto(0,05)$ yang berarti tidak terdapat hubungan antara sikap dengan pemeriksaan payudara sendiri di SMA Negeri 5 Pekanbaru.

Tabel 4. Ditrubusi Responden Berdasarkan Orang Terdekat Terhadap SADARI

\begin{tabular}{llll}
\hline No & Pernyataan & $\begin{array}{l}\text { Tidak } \\
\text { Melakukan }\end{array}$ & Melakukan \\
\hline 1. & Tidak Mendukung & $28(82,0 \%)$ & $6(17,6 \%)$ \\
\hline 2. & Mendukung & $41(56,2 \%)$ & $32(43,8 \%)$ \\
\hline & Total & 69 & 38 \\
\hline
\end{tabular}

Hasil uji Chi -Square diperoleh $p$ value $0,008<\propto(0,05)$ yang berarti terdapat hubungan antara orang terdekat dengan pemeriksaan payudara sendiri di SMA Negeri 5 Pekanbaru. 
Tabel 5. Ditrubusi Responden Berdasarkan Sumber Informasi Terhadap SADARI

\begin{tabular}{llll}
\hline No & Pernyataan & $\begin{array}{l}\text { Tidak } \\
\text { Melakukan }\end{array}$ & Melakukan \\
\hline 1. & Tidak Terpapar & $27(87,1 \%)$ & $4(12,9 \%)$ \\
\hline 2. & Terpapar & $42(55,3 \%)$ & $34(44,7 \%)$ \\
\hline & Total & 69 & 38 \\
\hline
\end{tabular}

Hasil uji Chi -Square diperoleh $p$ value $0,002<\alpha(0,05)$ yang berarti terdapat hubungan antara sumber informasi dengan pemeriksaan payudara sendiri di SMA Negeri 5 Pekanbaru.

\section{Pembahasan}

\section{Pengetahuan}

Berdasarkan hasil penelitian yang dilakukan di SMA Negeri 5 Pekanbaru didapatkan hasil $p$ value $0,234>\propto(0,05)$. Hasil Penelitian ini dikatakan tidak ada hubungan antara pengetahuan dengan pemeriksaan payudara sendiri di SMAN 5 Pekanbaru.

Penelitian ini tidak sesuai dengan teori Notoatmodjo, (2012) pengetahuan merupakan hasil "tahu" dan terjadi setelah seseorang mengadakan penginderaan terhadap suatu objek tertentu. Pengetahuan erat hubungannya dengan pendidikan, dimana diharapkan bahwa dengan pendidikan yang tinggi maka seseorang tersebut akan semakin luas pengetahuannya. Salah satunya mencari informasi mengenai kanker payudara dan pemeriksaan payudara sendiri yang sangat penting untuk terbentuknya tindakan seorang remaja untuk kesehatan dirinya sendiri.

Peneliti dapat menyimpulkan bahwa bahwa pengetahuan mempengaruhi pemeriksaan payudara sendiri tetapi pada penelitian ini menunjukkan hasil tidak terdapat hubungan antara pengetahuan dengan pemeriksaan payudara sendiri dikarenakan dari hasil kuesioner yang telah disebarkan kebanyakan dari remaja putri memiliki tingkat pengetahuan yang kurang mengenai pemeriksaan payudara sendiri. Namun, cenderung tidak melakukan pemeriksaan payudara sendiri. Hal ini dikarenakan kurangnya pengetahuan remaja putri tentang dampak dari kanker payudara.

\section{Sikap}

Berdasarkan hasil penelitian yang dilakukan di SMA Negeri 5 Pekanbaru didapatkan $p$ value $0,095>\propto(0,05)$. Dapat dikatakan tidak ada hubungan antara sikap dengan pemeriksaan payudara sendiri.

Penelitian ini tidak sesuai dengan teori Wahid (2009) rasa peduli juga merupakan sesuatu yang berkaitan dengan obsesi seseorang untuk menghindarai berbagai problem yang terjadi pada tubuhnya sehingga membutuhkan segala usaha dan perjuangan pada seseorang untuk membuat tubuh menjadi lebih sehat dan ideal sesuai dengan keinginan.

Peneliti menyimpulkan bahwa sikap mempengaruhi pemeriksaan payudara sendiri tetapi pada penelitian ini menunjukkan hasil tidak terdapat hubungan antara sikap dengan pemeriksaan payudara sendiri dikarenakan kurangnya rasa peduli remaja putri pada pemeriksaan payudara sehingga tidak ada keinginan melakukan pemeriksaan payudara sendiri.

\section{Orang Terdekat}

Berdasarkan hasil penelitian yang dilakukan di SMA Negeri 5 Pekanbaru didapatkan hasil $p$ value $0,008<\propto(0,05)$. Dapat dikatakan ada hubungan antara orang terdekat dengan pemeriksaan payudara sendiri. Dari hasil jawaban kuesioner orang terdekat, sebagian besar remaja putri di SMA Negeri 5 Pekanbaru mendapatkan dukungan dari orang terdekat mengenai pemeriksaan payudara sendiri.

Penelitian ini sesuai dengan teori Green, (2009) yang menyatakan bahwa perubahan perilaku terhadap tindakan kesehatan tergantung dari ada dukungan, adapun salah satu dukungan yang dapat diperoleh dari orang tua/keluarga, dengan demikian akan menjadi penguat bagi remaja putri yang memutuskan melakukan tindakan deteksi dini kanker payudara. Orang terdekat seseorang terdiri dari seluruh kelompok yang mempunyai pengaruh langsung terhadap sikap atau perilaku seseorang. Beberapa diantaranya adalah kelompok primer (adanya interaksi yang cukup berkesinambungan) seperti keluarga, teman, dan guru.

Hasil penelitian ini sejalan dengan penelitian Sari (2014) tentang determinan perilaku remaja putri dalam deteksi dini kanker payudara. Penelitian ini menyatakan bahwa secara statistik ada hubungan yang bermakna antara orang terdekat dengan pemeriksaan payudara sendiri pada remaja putri SMK Negeri 8 Medan dengan $p$ value $(0,000)<$ dari $\propto$ 0,05. Dukungan orang terdekat remaja putri didapatkan dari (Ibu, kakak, teman dan guru) 
Peneliti menyimpulkan bahwa orang terdekat bagi remaja putri seperti orang tua, saudara, dan teman dekat adalah seseorang yang berperan penting untuk mengajarkan atau memberikan dukungan yang sangat berpengaruh bagi individu untuk melakukan pemeriksaan payudara sendiri.

\section{Sumber Informasi}

Berdasarkan hasil penelitian yang dilakukan di SMA Negeri 5 Pekanbaru didapatkan hasil $p$ value $0,002<\propto(0,05)$. Dikatakan terdapat hubungan antara sumber informasi dengan pemeriksaan payudara sendiri. Dari hasil jawaban kuesioner sumber informasi, sebagian besar remaja putri di SMA Negeri 5 Pekanbaru terpapar sumber informasi mengenai pemeriksaan payudara sendiri.

Penelitian ini sesuai dengan teori Wahid, (20017) yang menyatakan bahwa sumber informasi dapat membantu mempercepat seseorang memperoleh pengetahuan yang baru. Semakin banyak sumber informasi, akan semakin baik pengetahuan seseorang untuk memperoleh pengetahuan yang baru. Sumber informasi merupakan tingkat pengetahuan dimana baik atau tidaknya pengetahuan tergantung pengetahuan kepada masing-masing individu dalam memahami dan menerima informasi yang diterima.

Peneliti menyimpulkan bahwa sumber informasi dapat menjadi salah satu faktor yang mempengaruhi pemeriksaan payudara sendiri pada remaja putri. Karena dengan adanya paparan media informasi menyebabkan remaja putri memperoleh informasi yang lebih banyak dibandingkan mereka yang tidak pernah terpapar media informasi tentang melakukan pemeriksaan payudara sendiri.

\section{Kesimpulan}

Hasil penelitrian ini menyimpulkan bahwa orang terdekat dan sumber informasi sangat mempengaruhi siswi remaja putri SMA Negeri 5 Pekanbaru dalam melakukan pemeriksaan payudara sendiri (SADARI).

\section{Ucapan Terima Kasih}

Terima kasih diucapkan kepada Ibu Ners. Dewi Kurnia Putri, M.Kep dan Ibu Yuyun Priwahyuni, SKM. M.Kes selaku pembimbing I dan II yang telah meluangkan waktu dan pikiran beliau dalam memberikan bimbingan, petunjuk dan saran kepada peneliti.

\section{Referensi}

- Jurnal

Agustina, E., Rahmayani, D., Yuliana, Fitri., (2015). Faktor-faktor Yang Berhubungan Dengan Perilaku SADARI Pada Remaja Putri di MA AL-Falah Puteri Banjarbaru. E-Journal. Diperoleh dari eva.agustina0308@gmail.com

Lubis, U. L., (2017). Pengetahuan Remaja Putri Tentang Pemeriksaan Payudara Sendiri (SADARI) dengan Perilaku SADARI. E- Journal Ilmu Kesehatan. Diperoleh dari http://ejournal.stikesaisyah.ac.id/index.php/eja

Sari, Y. P., Lubis, N. L., Syahrial, E., (2014). Determinan Perilkau SADARI Remaja Putri dalam Upaya Deteksi dini Kanker Payudara di SMK Negeri 8 Medan. E-Journal. Diperoleh dari

https://media.neliti.com/media/publications/14356-ID-determinan-perilaku-sadari remaja-putri-dalam-upaya-deteksidini-kanker-payudara.pdf

Wahyuni, D., Edison., Harahap, W, A., (2014). Hubungan Tingkat Pengetahuan dan Sikap terhadap Pelaksanaan SADARI. E-Journal. Diperoleh dari http://jurnal.fk.unand.ac.id

Wardhani, A. D., Saraswati, L. D., Adi, M. S., (2017). Kesehatan Masyarakat.

E Journal Volume 5, Nomor 1. E-Journal Diperoleh dari

http://ejournal-sl.undip.ac.id/index.php/j

- Buku

Arikunto, S., (2007). Manajemen Penelitian. Cetakan ketujuh, Malang : Rineka Cipta. American Cancer Society, 2008. Cancer Facts and Figures.

Budianto, B., (2013). Ilmu Perilaku penerbit Jakarta: Minabooks

Kartikawati, E., (2013). Awas Bahaya Kanker Payudara \& Kanker Serviks. Ed (1).

Dewi M, Wawan, A., (2010). Teori \& Pengukuran Pengetahuan Sikap dan Perilaku Manusia.Ed (2), Oktober 2011. Yogyakarta 
Nisman, W. A., (2011). Lima Menit Kenali Payudara Anda. Ed (1). Yogyakarta Olfah, Y., Mendiri, Dra, Ni Ketut., Badi'ah, A., (2013). Kanker Payudara SADARI. ED (1) Yogyakarta

Notoatmodjo, S., (2012). Promosi Keseshatan dan PerilakuKesehatan. Jakarta: Rineka Cipta

Setiati, E., (2009). Waspadai 4 Kanker Ganas Pembunuh Wanita. Ed (1) Yogyakarta: ANDI

- Artikel online

Dinas Kesehatan Privinsi Riau. Profil Kesehatan Provinsi Riau (2015) Pusat Data dan Informasi Kementrian Kesehatan RI., Situasi Penyakit Kanker(2015)

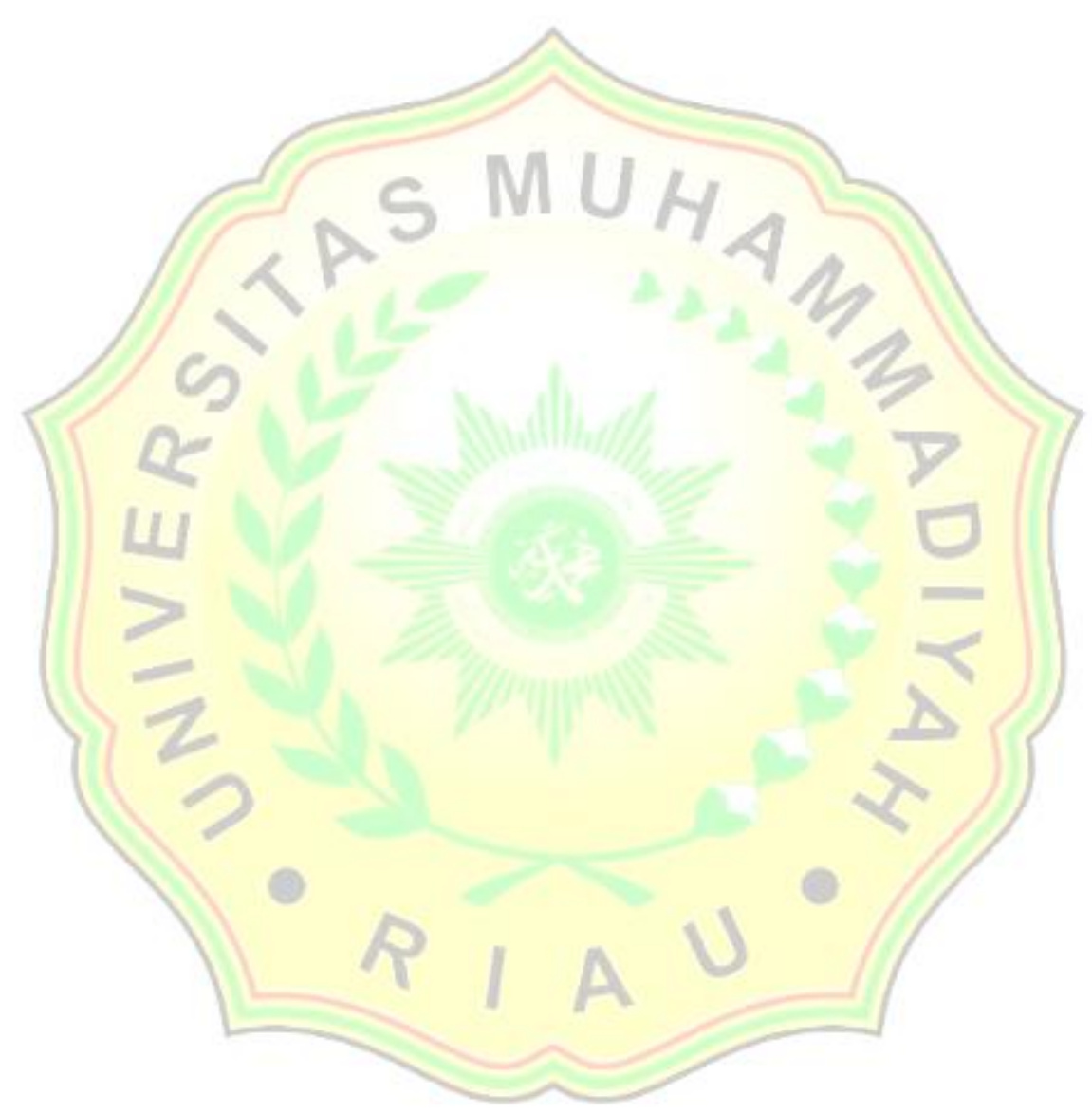

